\title{
The Effect of Small Side Games Exercise and Motor Ability Towards Students' Ability of Bunda High School Padang
}

\author{
Rizky Pratama ${ }^{1 *}$, Wilda Welis ${ }^{1}$, Adnan Fardi $^{1}$ \\ ${ }^{1}$ Sport Science Faculty, Universitas Negeri Padang, Prof. Dr.Hamka, Padang, Indonesia \\ "Corresponding author. Email: rizkhy.pratama260293@gmail.com
}

\begin{abstract}
The results of the first research hypothesis state that the average value of the small sided games training method A1 $=272.95$ is higher than the average score of the training series A2 $=264.8$. The second research hypothesis states that a group of high motor skills B1 $=273.25$ higher than the average score of low motor skills B2 $=264.5$. The third hypothesis states that Fcount $=11.03>$ Ftable $=4.06$. The fourth research hypothesis states that the average score of small side games AIB1 $=283.8$ is significantly higher than the average score of the training series $\mathrm{A} 2 \mathrm{~B} 1=262.1(\mathrm{Qh}=5.41>\mathrm{Qt}=3.88)$. The fifth hypothesis states that the average score of small sided games A1B2 $=262.7$ is significantly lower than the average score of the exercise series $\mathrm{A} 2 \mathrm{~B} 2=266.9(\mathrm{Qh}=1.23<\mathrm{Qt}=3.88)$. Conclusions The results of data analysis show that: $(1)$ the ability of basic football techniques between small sided games is better than a series of exercises, (2) there is an effect on the ability of basic football techniques that have high motor skills better than those with low motor skills ( 3 ) there is an interaction between the training method and motor skills on the basic skills of football techniques, (4) On high motor skills, the ability of the group's basic football techniques given small sided games is better than the exercise series, (5) On low motor skills the ability of basic football techniques given a series of exercises is as good as small sided games.
\end{abstract}

\section{Keywords: Basic Football Technical Ability, Small Sided Games, Training Series, and Motor Ability}

\section{INTRODUCTION}

Football games are one of the sports that are very popular today in any world. This is evident where people often play football in the afternoon sometimes to spend time with friends and also to improve body fitness that is busy with their activities all day. Not only in the city, but football also spread to villages or villages. Bunda High School is a school that has extracurricular activities which include scouts, dance and sports, which are precisely football. This football extracurricular activity is held twice a week on Saturdays and Sundays. Bunda High School carries out structured and programmed exercises.

The fact that occurred from observations seen by the author while doing a high school match at the Padang often experienced defeat. During participating in the high school matches, Padang always suffered losses even in the preliminary round matches which suffered losses and only once won.

Football is one of the complex sports, many factors can affect a person's ability to play football, these factors include physical, technical, tactical and mental conditions. All these components are interconnected and important for football players. Furthermore, adds "factors that can influence achievement in football practice, namely tactics, physical, psychological, and education"

Among these factors, factors in the physical condition and technique of the player have interrelated relationships. If the physical condition of a player is not good, it will be difficult to display good basic technical skills in the match. For example, basic football skills are passing, shoting, dribbling can be done well if the player has good speed, flexibility and agility to make movements so that the player is able to pass through the opposing player and put pressure on the opponent's defense area to create opportunity to create goals. Good mastery of techniques is needed in optimizing physical conditions.

Based on observations on the field when the Bunda Padang High School football team played a match on 15 September 2017 held by Padang Adabiah High School, in the first match of SMA Bunda Padang facing SKO Padang school with the results of the High School Bunda experience a 3: 2 thin defeat and at the match the second Bunda High School faced Padang Muhammadiah High School and again suffered a humiliating defeat of 3: 0 . During the match, the author saw and found many problems that occurred during the competition, namely the 
players' low skills, namely passing, dribbling and shoting, and also the physical condition of weak players.

Based on these data, it is alleged that the high school football player, Bunda Padang, did not master the basic skills of football. When dribbling the resulting movement is still less flexible, when doing many kicks that miss and are not on target as well as in the pass, there are still many who make a pass on their own friends so that the young ball is seized by the opponent. Less effective and less updated training factors also resulted in the deterioration and lack of development of games owned by the Bunda of Padang High School students. Also supported by inadequate facilities and infrastructure during the training process also resulted in a decline in the achievement of the Bunda of Padang High School football. The low motor skills of the high school students of Padang Padang when doing basic football techniques also affected so that the ability or skill to play the high school students of Bunda Padang did not develop to improve.

In general, this study aims to explain the effect of small sided games, a series of exercises and motor skills on the basic football skills of Bunda high school students in Padang. In particular, this research is to find out (1) the effect of the Small Side Games Exercise and Training Series on the basic technical skills of the football high school students of the Bunda Padang. (2) Effect of motor skills on the basic technical skills of football in the high school students of Bunda Padang. (3) The effect of the interaction between training methods and motor skills on the basic technical skills of football in the high school students of the Bunda of Padang. (4) Effect of Small Side Games Exercises with high motor skills on the basic technical skills of football in the high school students of the Bunda of Padang. (5) Influence of Training Series with low motor skills on the basic technical skills of football in the high school students of Bunda Padang.

\section{METHOD}

This type of research is quasi experiment, with the aim of research to determine the effect of small sided games training, a series of exercises and motor skills on the ability of basic football techniques. To determine the level of motor skills used quantitative research types and basic techniques skills with football skills tests [2]. After that it will be continued with a $2 \times 2$ factorial design. The study was conducted in UBH field, during the study in AprilMay 2018, the implementation of treatment in this study for four weeks with 4 meetings each week, so that the treatment for four weeks amounted to 16 meetings. The treatment will be adjusted to the conditions there.

One week before the treatment was used for the initial test data collection of basic football techniques and motor skills as a research moderator variable used to group samples into groups of high motor abilities and low motor abilities. The population in this study were all male students of the Bunda Padang High School class, amounting to 73 students. The sampling technique used in this study was random sampling seen from $27 \%$ of the population, thus the number of samples was 40 people.

\subsection{Instrument Development}

The implementation of the basic football technique ability test was carried out after measuring motor skills data. The results of the measurement of motor skills are then sorted from the highest score to the lowest score. After the results of the motor skills test are obtained then the macthing model is performed to divide into four sample groups. To determine the high and low categories of a score in the treatment group can be done by dividing group members by percentage techniques. The percentage technique in question is setting $27 \%$ of the high score group and $27 \%$ score for each group [3]. By using percentage techniques can be obtained the number of samples in the group of high motor abilities as many as 20 people and in the group of low motor abilities as many as 20 people. The number of samples was obtained from ( $27 \%$ of 73 people $=19.71$ rounded up to 20 people). The results of the grouping of experimental samples can be seen in the following table:

Table 1. Distribution of Samples for Each Cell.

\begin{tabular}{|l|l|l|l|}
\hline \multirow{2}{*}{ Motor ability $(\mathbf{B})$} & \multicolumn{3}{|c|}{ Exercise method (A) } \\
\cline { 2 - 4 } & $\begin{array}{l}\text { Small } \\
\text { sided } \\
\text { games } \\
\left(\mathbf{A}_{1}\right)\end{array}$ & $\begin{array}{l}\text { Series of } \\
\text { exercises } \\
\left(\mathbf{A}_{2}\right)\end{array}$ & total \\
\hline high $\left(\mathbf{B}_{1}\right)$ & & & \\
\hline low $\left(\mathbf{B}_{2}\right)$ & 10 & 10 & 20 \\
\hline total & 20 & 20 & 40 \\
\hline
\end{tabular}

The sample is given treatment according to the learning program that has been made. After the treatment is given, it is necessary to do basic football technique tests from the four groups, namely, two groups using small sided categorical exercises high motor skills (A1B1) and low (A1B2), then two groups used a series of exercises for high motor skills (A2B1) and low (A2B2). After drafting the research, a trial is needed on the instrument that will be used to gain confidence that the research design that has been chosen is sufficient to test the research hypothesis, the results of the study can be generalized in the study population. Thus it can be done controlling the internal and external validity of the research design.

The instrument used to measure motor skills is a test of speed, agility, balance and coorsination. Test the basic skills of football techniques using football skills tests namely dribbling, passig shooting and ball control. The final test in this study was conducted after the sample received treatment for 16 meetings. The purpose of this final test was to see the effect of motor skills on small sided games and a series of exercises for a sample of 40 students after being treated.

\subsection{Data Analysis Technique}

Data obtained from the research results were analyzed using two-way analysis of variance (anava) and followed by the Tuckey test when interactions were found between the motor reliability variable and the training method 
variable. Before the data is processed using variance analysis techniques, first anava requirement test is carried out, namely normality using the Lilliefors test and the variance homogeneity test using the Bartlett test with a significance level of $\alpha=0.05$.

\section{RESULTS}

\subsection{Testing the Requirements for Analysis of Variance}

The testing of the hypothesis in this study was carried out by using two-way analysis of variance (ANAVA). As a requirement for that test is required normality and homogeneity test of variance.

\subsection{Hypothesis testing}

Table 3. Anava Two-way summary of results for data skills of basic football techniques.

\begin{tabular}{|c|c|c|c|c|c|c|}
\hline $\begin{array}{l}\text { Varian } \\
\text { ce } \\
\text { Source }\end{array}$ & JK & Db & RJK & $\mathbf{F}_{\text {count }}$ & $F_{\text {table }}$ & \\
\hline & & & & & $=\mathbf{0 , 0 5}$ & \\
\hline $\begin{array}{l}\text { training } \\
\text { method }\end{array}$ & 765,63 & 1 & 765,63 & 5,03 & 4,08 & Sig \\
\hline $\begin{array}{l}\text { Motor } \\
\text { ability }\end{array}$ & 664,23 & 1 & 664,23 & 4,37 & 4,08 & Sig \\
\hline $\begin{array}{c}\text { Inter } \\
\mathrm{AB}\end{array}$ & 1677,02 & 1 & 1677,02 & 11,03 & 4,08 & Sig \\
\hline $\begin{array}{l}\text { Inner } \\
\text { error }\end{array}$ & 5475,50 & 36 & 152,10 & - & - & \\
\hline Total & 8582,38 & 39 & & - & - & \\
\hline
\end{tabular}

\subsubsection{Differences in the Effect of Basic Technical Ability in Small Sided Games Training Groups and Training Circuits}

Table 4. Anava Results in the Advanced Stage with Tuckey Test.

\begin{tabular}{|c|c|c|c|c|}
\hline $\begin{array}{l}\text { Sample } \\
\text { group }\end{array}$ & $\begin{array}{c}\text { Number } \\
\text { of } \\
\text { sample }\end{array}$ & $\mathrm{L}_{\text {count }}$ & $\mathrm{L}_{\text {table }}$ & $\begin{array}{l}\text { conclusio } \\
\mathrm{n}\end{array}$ \\
\hline A1 & 20 & 0,1254 & 0.190 & Normal \\
\hline A2 & 20 & 0,1021 & 0,190 & Normal \\
\hline B1 & 20 & 0,1201 & 0190 & Normal \\
\hline B2 & 20 & 0,1065 & 0,190 & Normal \\
\hline A1B1 & 10 & 0,2186 & 0,258 & Normal \\
\hline A1B2 & 10 & 0,1754 & 0,258 & Normal \\
\hline A2B1 & 10 & 0,1460 & 0,258 & Normal \\
\hline A2B2 & 10 & 0,1575 & 0,258 & Normal \\
\hline
\end{tabular}

The results of the testing of the first hypothesis show that overall, improving the ability of basic football techniques in the small sided games training group method is higher than in the training group. In other words, the proposed research hypothesis is significantly proven. From these findings it can be stated that the method of small sided games is more effectively used to improve the ability of basic football techniques. This can be seen from the results of statistical analysis with a mean difference of 8.75 which means that exercise using small sided games provides a better influence than training using a series of exercises.

The effectiveness of small sided games is supported by an atmosphere of cohesiveness and lots of games that make the atmosphere of the exercise fun and not boring. Unlike the case with a series of exercises in which students are taught alternately, so students are long enough to wait their turn. In the process of a series of exercises, students develop individually, this means that students do not care about other students who want to improve their basic skills in football have an impact on improving football skills, for students who have high motor skills the results of their basic football skills will increase significantly while for students who have low motor skills it will be difficult to improve the ability of basic football techniques. Thus, students will experience difficulties in developing their skills as desired.

The trainer is an external factor that can affect motor learning. According to the teaching factor or facilitator is the extent to which a teacher is able to guide and create the atmosphere so that the process of motor learning can run well and be successful [4]. Thus, the coach's decision in choosing the training method that will be used in motor learning, the ability of the trainer is important in achieving the objectives of the training.

\subsubsection{Differences in the Effect of Basic Football Technical Abilities that Have High Motor ability and Low Motor ability}

In accordance with the second hypothesis, there is the influence of the ability of basic football techniques that have high motor skills and low motor skills, it turns out the results of hypothesis testing prove that there are differences in the influence of basic football skills between high motor skills and low motor skills submitted is proven to be significant. This means that high motor skills are better than low motor skills on the ability of basic football techniques.

Motor skills are a determining factor for basic movements of football whose purpose is football ability. "Motoric ability is the process by which an individual develops his ability to move into a coordinated, controlled, and regular response" [5]. With motor skills a person can do all his activities properly. If the motoric ability is disrupted, it will inhibit other abilities, such as the ability to socialize and the ability to do tasks or daily activities.

From the above opinion it can be concluded that if a person's motoric abilities are interrupted then it will have an impact on other abilities similar to high and low motor skills which will affect the ability of basic football techniques if high motor skills will have a good impact on the ability of basic football techniques and when motor skills are low it will have a negative impact on the ability of basic football techniques. 


\subsubsection{Interaction between motoric training and ability methods with basic techniques abilities}

In connection with the hypothesis about the interaction between independent variables and moderator variables, it turns out that the results of hypothesis testing prove that there is an interaction between training methods and motor skills in their influence on the ability of basic football techniques, or in other words that the proposed research hypothesis is significantly tested. This means that the training methods and motor skills together have an influence on the ability of basic football techniques, or in other words the effect of training methods on the ability of basic football techniques is dependent on motor skills.

In groups of students with high category motor skills who use small sided games exercise get higher results when compared with groups of students with the same motor skills using the training series method. Conversely, in the group of students with motor skills in the low category using the series method obtained higher results than the small sided games exercise, in other words that in the category of low motor skills the training series method was more effective than small sided games.

Based on the discussion above, there is an interaction between motor skills and training methods that are used to the ability of basic football techniques. Interaction between training methods and the ability of basic football techniques as described above can be illustrated through a comparison of the average score of basic football technique abilities between groups of students with high and low categories with different treatments as follows.

\subsubsection{At High Motor Ability, Small Sided Games Exercises Are Better Than A Series Of Exercises Against Basic Techniques Of Football Ability}

The results of hypothesis testing show that overall, the group's basic football technique ability score given a small sided games exercise was higher than the group given a training series method on high motor skills. In other words, the proposed hypothesis is accepted. From these findings it can be argued that the ability of basic football techniques given small sided games is more effective than the training series on high motor skills.

In applying small sided games, the trainers' creativity was asked to design a fun training program so that students who were trained were not lazy or bored when doing exercises because small sided games were exercises that contained many modified games so that the training session was fun. Furthermore, in the method of small sided games how to play games have limitations. According to Kadir Yusuf in Restrictions through nerves or special game rules for example with regulations may only touch the ball once or twice [6]

Motor skills are one of the external factors in improving football skills. With high motor skills students have adjustments to the exercises that aim to make it easier for them to complete or master the skills to play football. Students who have high motor skills are characterized by good movements in following the training process. With high motor skills students will be diligent in the face of training this will have an impact on the concentration of students in absorbing the training programs provided by the coach. The high concentration will be able to absorb the information obtained. Then based on the information obtained will be able to proceed to the reaction to be able to adapt to the environment they have. Thus ideally high motor skills will be able to influence students' activities in football practice.

In the small sided games training method, high motor skills can be characterized by the students' desire to do the movements instructed by the trainer, the trainer will make corrections to the techniques performed by the students, and after correction, students try again the same movements in the hope that the movements are then it will be better. In contrast to students with a series of exercises with high motor skills, students cannot do new movements on their own because they have to be fixed on group members, this causes students to feel bored quickly because the material given is fixed on just one training material.

\subsubsection{At Low Motor ability, The Method Of Training Series Is Better Than Small Sided Games Against Basic Techniques Of Football Ability}

The results of hypothesis testing showed that overall, the students' basic football technical skills scores in the group given the method of training were better than those given small sided games on low motor skills. In other words, the proposed hypothesis is rejected. From these findings it can be stated that the series of training methods are no different from small sided games on low motor skills. In other words, both methods of training are equally good for improving the ability of basic football techniques with low motor skills.

in a series of training methods students do individual exercises to achieve a common goal despite having different abilities. a series of exercises is an exercise program that focuses on just one material in other words this method is very helpful for students who have low motor skills with this series of exercises to make students more passive about a movement and basic techniques of football.

By applying the training series method the trainer indirectly increases students' motor skills. So in low motor skills when the series method is applied, the student's motor skills in training can increase so that the results of the exercise are better when compared to the implementation of small sided games in low motor skills. But it does not rule out the possibility that low motor skills are also effective in using small sided games because in the small sided games exercise many movement elements are used in sepabola so that those who have low motor skills can also improve their basic football skills. Because of that there is no difference between the two methods of training to improve the ability of basic football techniques on low motor skills.

\section{CONCLUSIONS}

Based on the findings of the research and discussion of the results of the study it can be concluded (1) Overall 
the ability of basic football techniques for small sided games students is better than the series of exercises (2) Overall the basic skills of football students who have high motor skills are better than motor skills low (3) There is an interaction between the training methods and motoric abilities of students' basic football skills. (4) On high motor skills, the basic skills of football techniques of group students who were given small sided games were better than those given the training series method. (5) In low motor skills, the basic skills of football techniques of group students who were given a series of exercises were as good as groups given small sided games. Based on the conclusions stated above, it can be explained that the training methods used and motor skills have an interactive effect on the ability of basic football techniques. This means that the form of approach or training method (small sided games and series) has a different influence on the ability of basic football techniques if associated with motor skills

Based on the results of the study, the method of small sided games is more effective in improving the ability of basic football techniques. Based on the conclusions and implications above, it is expected to: (1) The trainer, in an effort to improve the ability of basic football techniques, the trainer can apply the method of small sided games and training exercises. (2) The trainer, in an effort to improve the ability of basic football techniques, the trainer should consider the factors of students 'motor skills, because there is an interaction between students' motor skills and training methods. (3) If the student's motoric ability level is low, the trainer can apply a series of training methods to improve the ability of basic football techniques. (4) If the level of motoric ability of students is high, the trainer should apply small sided games to improve the ability of basic football techniques.

\section{REFERENCES}

[1] Leontijević, Bojan., Janković, Aleksandar.,\& Sofronijević, Filip, "Comparative Analysis Of Football Technical Competitive Activity Between Uefa Champions League And Serbian Superliga," J. PHYSICAL CULTURE; 69(2), pp, 129-137. 2015.

[2] Arsil, "Evauasi Pendidikan Jasmani Dan Oahraga," Malang; Wineka Media, pp, 35-44. 2015

[3] Atmaja, N. Moh. K \& Tomoliyus, "Pengaruh Metode Latihan Drill Dan Waktu Reaksi Terhadap Ketepatan Drive Dalam Permainan Tenis Meja," J. keolahragaan. Vol. 3. No. 1, pp, 78-82. April. 2015.

[4] Rahyubi, Heri, "Teori-Teori Belajar Dan Aplikasi Pembelajaran Motorik," Jawa Barat.; Referens. 2012.

[5] Didik Cahyo Wicaksono, "Survey Kemampuan Motorik Siswa Sekolah Dasar Muhammadiyah Kelas Iv Se-Kecamatan Taman Sidoarjo Tahun
Ajaran 2012 -2013," J. Pendidikan Olahraga dan Kesehatan Volume 01 No. 01,pp, 98-103. 2013.

[6] Nadwi Syam, "Pengaruh Latihan Small Sided Games Terhadap Kemampuan Menggiring Bola Dalam Permainan Sepakbola Pada Siswa Smk Negeri 5 Makassar," J. Competitor. Nomor 2 Tahun 2. Jun. 2010 